\title{
ROLE OF HONEY STOMACH IN THE DIGESTION OF HONEY BEE APIS CERANA INDICA (F.)
}

\author{
Buddhe Gajanan*, Shinkhede Milind** and Masram Suresh* \\ *Department of Zoology, RTM Nagpur University, Nagpur (M.S.), 440033 \\ **Dada Ramchand Bakhru Sindhu Mahavidyalya, Nagpur (M.S.), 440017 \\ Corresponding author's email: shinkhedemilnd@gmail.com.
}

\begin{abstract}
:
In the honey bee the oesophagus expand into a large thin walled sac, commonly called crop or honey stomach. The honey stomach is well developed in the worker and play vital role to hold the nectar and accumulate in this reservoir. Basically honey stomach is in the form of sac with distensible walls. Histologically wall of honey stomach shows high folds in its epithelium enormous expansion of the sac. Scanning electron micrograph show epithelial pleats suggests the role in nectar processing. Histology of midgut also supports as the holocrine mode of secretion.
\end{abstract}

\section{Keywords: Crop, Epithelial pleats, Midgut Histology, Apisceranaindica}

\section{INTRODUCTION:}

The morphological and histological organization of alimentary canal of ApisceranaindicaFabricius is similar to Apismellifera. Alimentary canal is divided into three regions namely foregut, midgut and hindgut. Foregut is differentiated into pharynx, oesophagus, crop and proventriculus. All these parts are provided with well developed musculature. Extrinsic muscles are attached to the foregut and hindgut and works as dilators in insects ( Snodgrass, 1953; 56;).

When a worker with its honey stomach filled with nectar reaches the hive, the nectar is either store directly in the cell or is given up to first to some other worker, who placed in a cell. The crop wall consist of three layers, the innermost is the epithelium with its cuticular intima and surrounded by two muscle layer and inner longitudinal layer and outermost circular layer (Schreiner, 1954, Brosch and Schreiner,1985). The cuticle consist of a thin epicuticle and thick procuticle with pore channels.
The proventriculus is highly specialized part of the foregut. In some insects, process of grinding the food into fine particles takes place largely in the proventriculus (Wiggleworth, 1927). The function of proventriculus in the worker is however to regulate the flow of food material from crop into the ventriculus and to the cells of the hive.

\section{MATERIAL \& METHODS:}

In order to explore physiology of digestion and enzyme production in the commercially domesticated Indian honey bee, $A$. ceranaindica the present work has been undertaken, with materials and method describe below.

Honey which is made from the regurgited nectar, thus indeed contain some pollen but most of the pollen eaten by the bee is retain in the stomach as food. In the present study we have to explore the construction of the crop wall and processing of nectar in the honey stomach.

\section{A) Material}

The honey bee, A. cerana F. occurs in Japan, China, India and other East Asian countries. It is widely distributed in India. The taxonomic 
status of this species has been established by Fabriceous in 1793 and Lindauerand Kerr (1960) suggested A. ceranaindica to be a correct name for the India hive bee.

A colony of $A$. ceranaindica has been established in two storied, ten framed Langstroth wooden hive at the garden of department of Zoology, RTM Nagpur University Campus, Nagpur through the year 2014-2018. During the present study, the bee- keeping procedures of Wadhwani and Chhabra (1972) and Singh (1975) have been followed.

During the present study, the bees were collected, whenever required from the established colony. The colony is found over populated during winter season while it is generally reduced during summer due to variation in flora and environmental conditions. In order to prevent swarming, queen cell were immediately destroyed and favorable conditions were artificially made (Singh, 1975). The following procedures were carried out.

\section{B) Methods}

\section{Histological preparation}

Fixation:

Honey bees were dissected under a stereoscopic binocular microscope and excised the alimentary canal, washed in a Ringer's solution. These tissues processed for histology, Bouin's fluid (aqueous) fixative used for histological studies,

Embedding and sectioning:

Tissues fixed in Bouin's fixative were transferred to $70 \%$ alcohol, dehydrated, cleaned in paraffininfiltrated xylene and blocks prepared. For the block-making process, glass lids of staining jars and' L' brass parts were used as moulds. With a thin layer of glycerol, the moulds were internally powdered and molten paraffin wax was poured up to the brim in the moulds. To remove trapped air, the hot needle was passed in the molten wax and the tissue was gently placed at the desired orientation in the wax bed. Half an hour later, for uniform solidification and cooling of the wax bed, the mould was immersed in a water container. Tissues were cut at $6-8 \mu \mathrm{m}$ on a rocking microtome (Cambridge model) in transverse sections and mounted on a slide.

Sections were deparaffinized in xylene and passed down alcohol levels to the water. Then stained in hematoxylin (5-10min) and kept in running water. The sections were kept in eosin (10min). Then sections dehydrated through a series of alcohol up to $90 \%$ to absolute alcohol for $10 \mathrm{~min}$ each. Cleared the section in xylene for 10 min then sections were mounted in DPX. The slides were microscopically examined (Karl Zeiss) and photographed in Tuscon camera.

Scanning Electron Microscopic (SEM) study of the crop, midgut and intestine in Apisceranaindica

The Apisceranaindica was dissected, tissues were taken out washed with phosphate buffer (PB) then selected tissues were placed in fixative prepared by mixing $2.5 \%$ glutaraldehyde containing 2\% paraformaldehyde in $0.1 \mathrm{M}$ PB. The $\mathrm{pH}$ of $\mathrm{PB}$ was maintained at 7.4. Tissues were kept in fixative overnight. After fixation, tissue was washed with PB 2 to 3 times. Tissues were then dehydrated in the graded series of alcohol i, e 30\%,50\%, 70\%, 90\% and absolute alcohol. After treatment by graded series of alcohol, tissues were subjected to complete critical point drying. Finally, tissue was coated with gold to be observed under an under Zeiss EVOMA10 and JEOL 6380A scanning electron microscope at $20 \mathrm{kV} / \mathrm{EHT}$, Visvesvaraya National Institute of Technology, Nagpur.

RESULT \& DISCUSSION:

Observation:

Crop

Cross section of honey stomach of worker bee shows elongated and separated epithelial layer. Basement cells are brush bordered to permit the 
pollen grain pass to the ventriculus. Basement cells forms a solid layer in the nurse and forager bee. Some chitinic processes were detected with epithelial layer (Fig. 1a, Fig.1b, and Fig.1c).

\section{Midgut}

The midgut wall is composed of three layers; outer longitudinal muscles, middle circular and inner epithelial layer. The large number of longitudinal muscle layer strands is present above circular muscle layer. Externally, longitudinal muscles strands are covered by a thin peritoneal membrane. Circular muscle is extended into the epithelial folds to a great dept. The epithelium is thrown into seven to eight folds.

The epithelium is composed of two types of cells, regenerative cells and columnar cells. At the basal region of epithelium, regenerative cells are arranged into crypts. The regenerative cells show large nuclei, scanty cytoplasm and then cell wall.

The columnar cells are long, with brush border and large nuclei at centre with cytoplasmic inclusions. Fully filled vesicles are present in the lumen of columnar cells the peritropic membrane is well distinct in the lumen of the midgut and it encloses the food materials.

Scanning electron micrographic study of crop shows extensive support of circular and longitudinal muscle layers (Fig. 3d and Fig.3e). Inner wall of crop is lined with basement membrane and villi are present which helps in digestion and absorption (Fig. 3b and Fig.3c.) Epithelial pleats are also present to increase the capacity of crop during nectar collection process Fig. $3 \mathrm{c}$ and $3 \mathrm{~d}$.

Honey bee nectar gathering even though their crops are not full, due to fight cost budgeting. Furthermore, there is no consideration of possibility that honey may leave the hive for continued foraging with crops that have not been fully emptied. The size of the crop and its capacity for enlargement also might be necessity during swarming or absconding activity, when bees are carrying all their food reserve in their bodies to establish a new colony. This extra food is need to activate that produce bee wax, the material bees use for their nest (SchmidHempelet al., 1985).

During dispensation of nectar in the hive, the muscular enclosure contracts and forces the epithelium to pleat, itself again, pleats are present in even the most glossy distended crop, indicating that capacity is not a limiting factor in the volume of nectar, a bee can accumulate during foraging. Individual pleats are appressed, too, indicating that a lubricating, cohering substance occur between them (Sammataro and Circero 2010).

Mucopolysaccharide were found in the basal membrane of the midgut epithelium cell and peritropic membrane of Apismellifera. The main function of the peritropic membrane was to distribute the digestive enzymes evenly through the midgut (Zherebkin, 1967).

Standifer (1977) recorded that the digestion process of honey bee workers depends on the activity of enzymes present in the secretion of the salivary, post cerebral and hypopharyngeal glands and in the secretions of the midgut epithelial cells.

The regenerative cells live close to the basal membrane of crop epithelium and have the function of regeneration; usually they are solitary and sometime two or three together in a group. Regenerative cell produce mitotically and differentiation take place in daughter cells ( De Priester,1971; Willie, 1983). The similar regenerative cells division, differentiation and propagation were observed in Apisceranaindical Barsagadeet al., 2008).

Spatial separation of specialized columnar cells in the insect midgut may partially confine enzyme secretion to one section of the gut and 
nutrient absorption to another (Berridge 1970; Bignellet.al., 1982; Schneider et al.,1987). Further segregation of digestion occurs because the peritropic membrane partitions the gut, thus permitting sequential digestion in spatially separate compartments within the midgut lumen. Primary digestion occurs within endoperitropic space and then terminal digestion completedat brush border (Terra et al., 1979, 1985 ). The establishment of these compartments occurs in the honey bee midgut, as it does in many insect, when the epithelial tissue secretes the peritropic membrane.

This elongated epithelial layer plays a key role in a physiological process in the honey ripening. These cells also help to secrete specific enzymes for honey ripening. Enzyme like amylase invertase, glucose oxidase have been regulated in higher concentrations in honey stomach in nurse bees (Zakaria, 2005). It shows the role of nurse bee in completely digestive process.

In Apisceranaindica the midgut, similar to that in other honeybees, is a long tubular structure consisting outer layer of longitudinal muscles, middle layer of circular muscles and inner layer epithelium and later one is differentiated into two types of cells, the minute regenerative cells forming the basal crypts and tall columnar cells performing digestion and absorption ( Snodgrass, 1956; Wigglesworth 1965; Chapman 1985 a; Chapman 1985 b).

During the present study, histological structure of crop was studied and revealed the presence of basement cells and elongated epithelial cells in the crop wall. These cells help to process nectar and pollen. Epithelial pleats also suggest the role in digestion. The histological observations of midgut show that the midgut wall is composed of outer longitudinal muscles, middle circular muscles and internal layer of epithelium. The epithelium is composed of two types of cells, the regenerative cells and columnar cells.
Membranous vesicles filled with deeply stained material occur predominantly in extra peritoneal region which seems to detach from the columnar cells suggesting holocrine mode of secretary mechanism.

\section{CONCLUSION:}

Honey stomach is enriched with epithelial pleats suggests the role in digestion. It is observed in scanning electon microscopic studies that extensive muscle layer supports distensible wall of honey stomach for expansion of sac. Histology of midgut shows presence of regenerative cells, columnar cells suggests the regulation of digestive processes in the Apisceranaindica.

\section{REFERENCES:}

Barsagade D. and Kelwadkar K (2008) Ultrastructural Changes In the Midgut During Metamorphosis in ApisceranaIndica, Int. J. Indust. Entomol. Vol. 16, No. 1, pp. 29-35.

Berridge M. J. (1970) A structural analysis of intestinal absorption. Symp. R. Entomol. Soc. Lond. 5, 135-153.

Bignell D. E. ,Oskarsson H. And Anderson J. M. (1982) Formation of membrane bounded secretory granules in the midgutepitheliumof a termite, Cubitermesseverus and a possible intercellular route of discharge. Cell tissue Res. 222,187-200

Brosch, U., and L. Schneider. (1985). Fine structure and innervation of the honey stomach (crop) of the honeybee, Apismellifera L. (Hymenoptera: Apidae). Int. J. Insect Morphol.Embryol. 14: 335-345.

Chapman, R.E. (1985a). Co-ordination of digestion. In: Kerkut, G.A. and Gilbert, L.1. (eds.). Comprehensive Insect Physiology, Biochemistry and Pharmocology.Pregaman Press, Oxford 4: 213-240. 
Chapman, R.E. (1985b). Co-ordination of digestion. In: Kerkut, G.A. and Gilbert, L.1.(eds.). Comprehensive Insect Physiology, Biochemistry and Pharmocology. Oxford, Pregaman Press, 4:165-211.

Day ,M. F. and Powning, R.F. (1949) A study of process of digestion in certain insects. Aus. J.Sci. Res. (B)2: 175-215.

De Priester, W. (1971).Ultrastructure of midgut epithelial cells in the fly, Calliphoraerythrocephala. J. Ultrastru. Res. 36: 783-805.

House, H.L. (1974). Digestion: In physiology of Insecta (Ed. M. Rockstein), Academic Press, New York 5: 66-111.lnternat. Conf. Apicult. Tropical Climates. Div. Emtomol. IARI., New Delhi., 367-371.

Lindauer, M. And Kerr, G. (1960).Bee world, 41:29.

Schmid-Hempel, P., A. Kacelnik, and A. I. Houston. (1985). Honeybees maximize efficiency by not plling their crop. Behav. Ecol. Sociobiol. 17: 61-66.

Schneider F., Houseman J. G. And Morrison P.E. (1987) Activity cycle and the regulation of digestive proteases in the posterior midgut of Stomoxyscalcitrans(L.) (Diptera: Muscidae). Insect Biochem.17,859-862.

Schreiner, T. (1952). Uber den nahrungstransportimdarm der honigbiene. Z. Vgl. Physiol. 34: 278-298.

Singh S. (1975) Bee keeping in India ICAR New Delhi.

Snodgrass R. E. ( 1956) Anatomy of the honeybee. Vail Ballou Press, Inc., Binghmton New Yok. 347-387.

Snodgrass, R. E. (1956). Anatomy of the honeybee.Comstock Publishing Associates, Ithaca, NY.

Standifer, L.N., (1977). Honey bee nutrition and supplemental feeding. Mid Atlantic Apiculture, Htm. PP. 1-8.
Terra W. R. , Ferreira C \&Bastos F ( 1985) Phylogenetic consideration of insect digestion. Disaccharidases and spatial organizationof digestion in the Tenebriomolitor larvae.Insect Biochem.15,443-449.

Terra W. R. , Ferreira C. \& De Bianchi A. G. ( 1979) Distribution of digestive enzymes among the endo and ectoperitropic species and midgut cell of Rhynchosciara and its physiological significance J. Insect Physiol. $25,487-494$

Terra, W. R. (1988).Physiology and biochemistry of insect digestion.An evolutionary perspective.Braz. J. Med. Biol. Res. 21: 675734.

Terra, W.R. (1988).Physiology and biochemistry of insect digestion.An evolutionary perspective.Braz.J. Med. Biol. Res., 21, 675-734.

Wadhwani, A. M. And Chhabra, N. N. (1972).Bee Keeping In India.Icar New Delhi

Wigglesworth, V.B. (1965). The principles of Insect Physiology, Methuen and Co. Ltd., London.

Wiggleswotrth, V.B. (1927). Digestion in the cockroach 11.The digestion of carbohydrates.Biochem. J. 21: 797-81

Wiggleswotrth, V.B. (1972). The principles of insect physiology. $7^{\text {th }}$ Ed. New York N.Y. John Willey and Sons, Inc.827.

Willie A. ( 1983) A biology of stingless bees. Ann. Rev, Entomol 28, 51-61.

Zakaria, M.E., (2005). Effect of infection with Nosema disease (Nosemaapis Z.) on some biochemical activities of honey bee workers (Apismellifera L.) (Hymenoptera :Apidae). Bull. Ent. Soc. Egypt, Econ. Ser., 31: 107113.

Zherebkin, M.V., (1967). Secretion of digestive enzymes in the midgut of the worker bee.The $\mathrm{xx} 1$ st International Apicultural 
congress, Maryland.Apimondia Publishing

House, Bucharest, p.476.

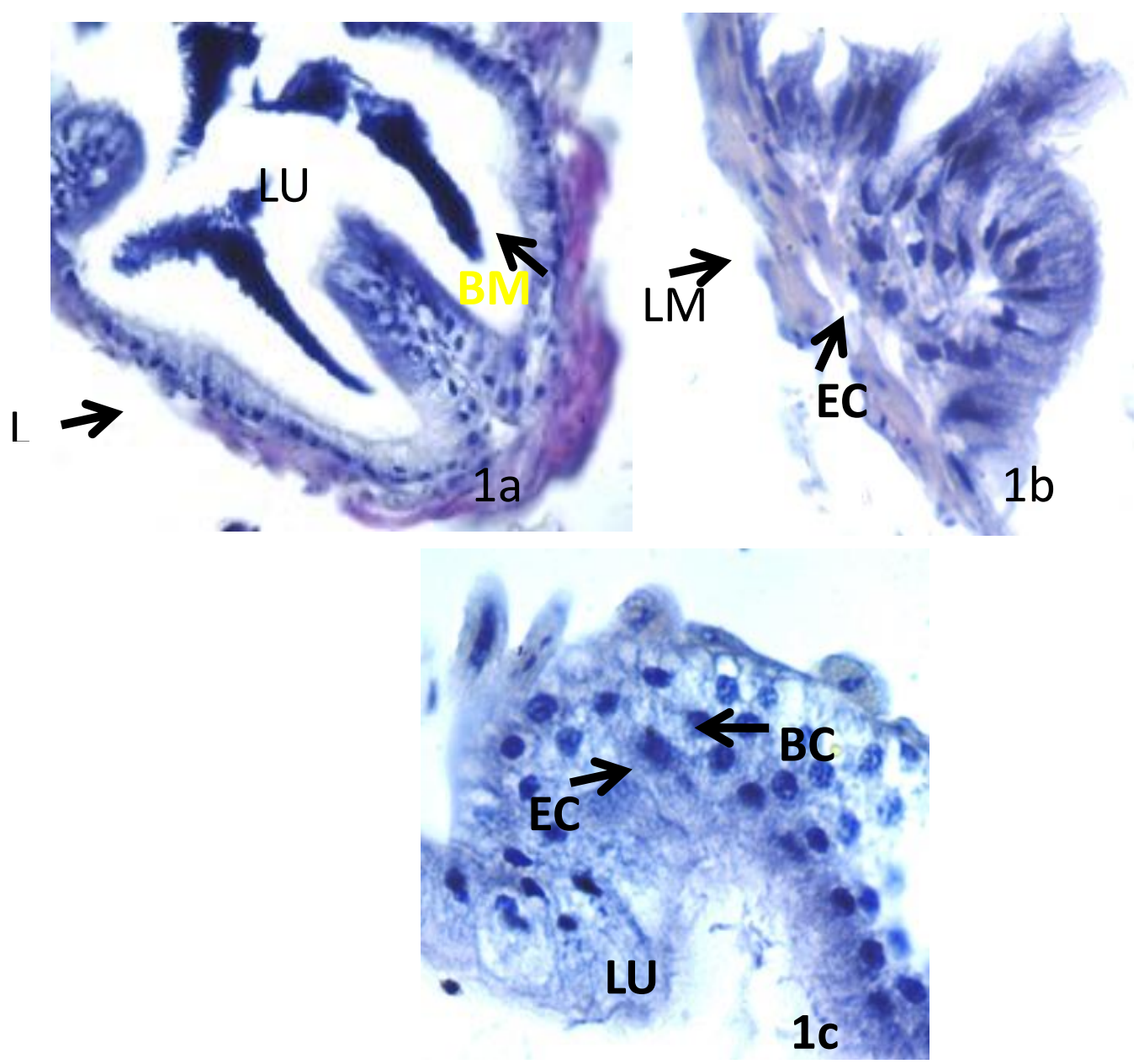

Fig. 1a : Section showing histological structure of crop with lumen with food particles and longitudinal muscles (LM) in crop. HE: 100X

Fig. 1b : Section showing longitudinal muscles (LM), epithelial cells(EC). HE 400X Fig. 1c : Section showing epithelial cells(EC), lumen(LU) and basal cells(BC).400X Abbr: EC- Epithelial cell, EF- Epithelial folds, LM- Longitudinal muscle, LU Lumen, BM- Basement membrane, BC-Basal cells 

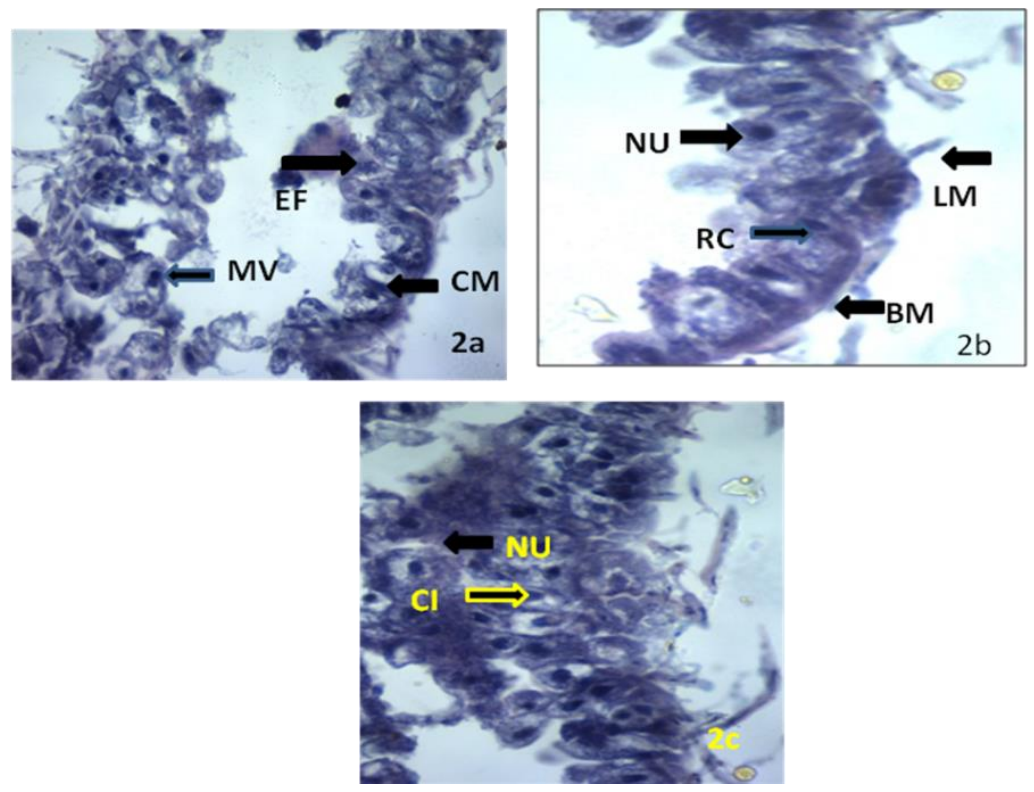

Fig. 2a : Section showing histological structure of midgut exibiting epithelial fold (EF), membranous vesicles(MV) and circular muscles (CM) 400X

Fig. $2 b$ : Section showing basement membrane(BM), regenerative cells (RC), peritropic membrane(PM), nucleus(NU). HE 400X

Fig. 2c : Section showing epithelial cells(EC), nucleus(NU). HE 400X

Abbr: CM-Circular muscle, EC- Epithelial cell, EF- Epithelial folds, LM- Longitudinal muscle, , MV Membranous vesicles NU -Nucleus, BM- Basement membrane, CI-Cytoplasmic inclusion.
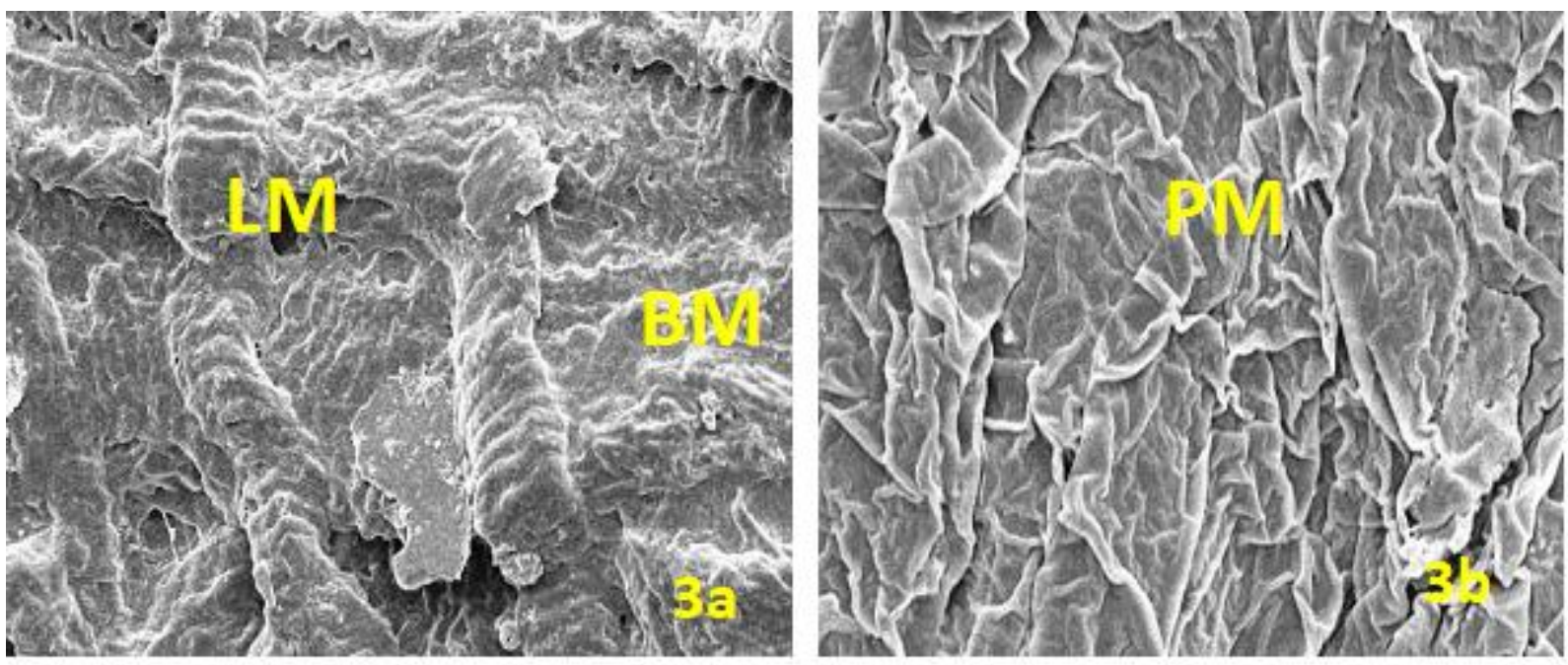

Fig 3a-SEM of crop showing internal structure with well developed longitudinal muscles(LM), basement membrane(BM). Scale bar $=10 \mu \mathrm{m}$

Fig. $3 b$ and $3 c-$ SEM of crop showing epithelial folds(EF). Scale bar $=5 \mu \mathrm{m}$ 

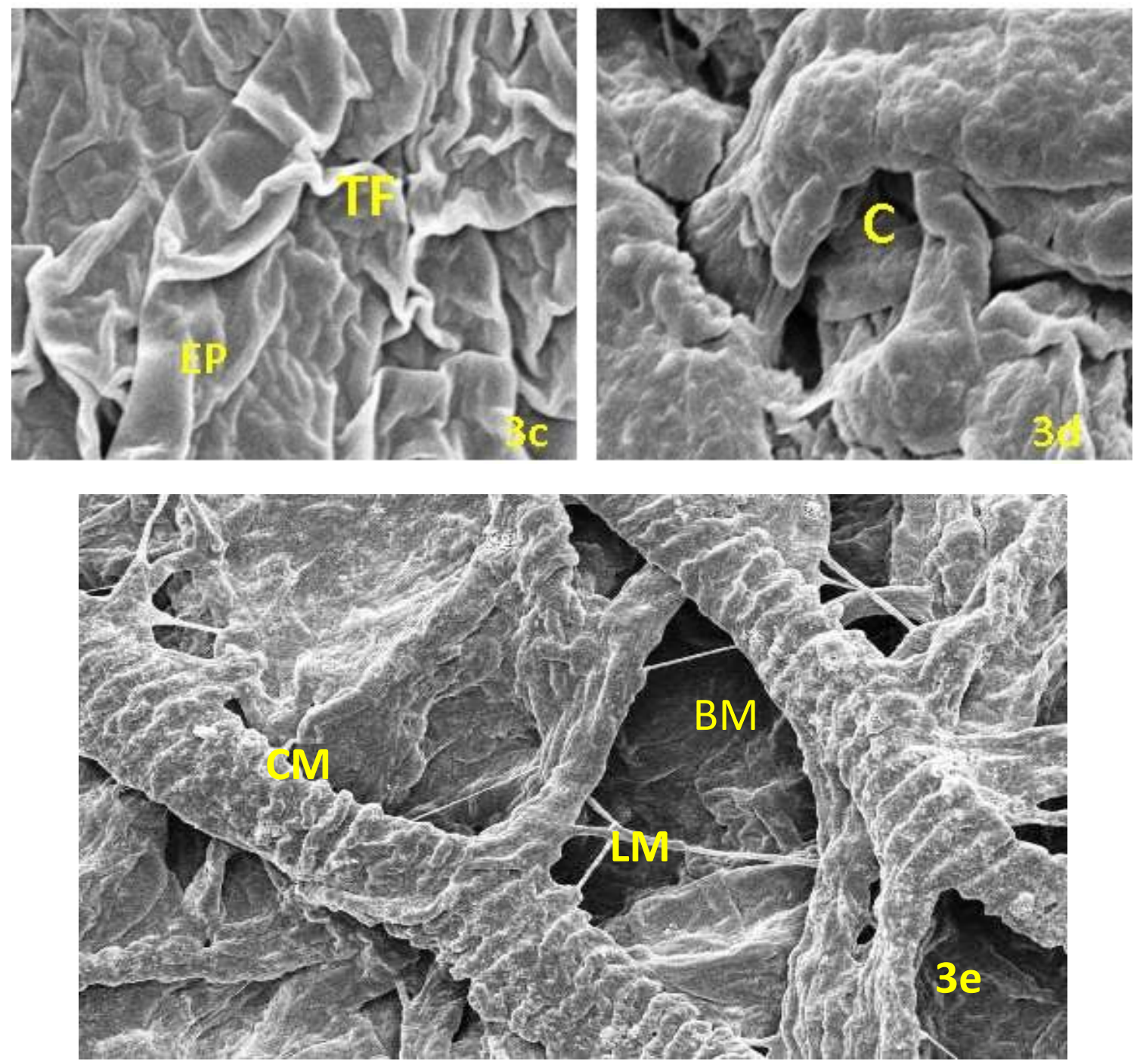

Fig. 3d and 3e SEM of midgut showing well developed circular muscles(CM) and longitudinal muscles(LM). Scale bar $=1 \mu \mathrm{m}$

Abbr. CM - circular muscles, EP- epithelial plate, BM -basement membrane 